\title{
REGENERATION STATUS OF SAL (Shorea robusta GAERTN.) IN COMMUNITY MANAGED FORESTS, TANAHUN DISTRICT NEPAL
}

\author{
Prativa Poudel, Anjana Devkota* \\ Central Department of Botany, Tribhuvan University, Kathmandu, Nepal \\ *Corresponding author: devkotaa@gmail.com \\ (Received: May 06, 2021; Revised: September 30, 2021; Accepted: September 30, 2021)
}

\begin{abstract}
The present research aims to know the regeneration status of community managed Shorea robusta (Sal) forests; managed for 6-21 years in Tanahun district, a part of Gandaki Province, Nepal. These forests were categorized into two groups according to management duration (more than 10 years and equal or less than 10 yrs). The regeneration status of the forest was estimated by calculating the density of each species in each developmental phase (seedling, sapling and tree). The total tree density of community forest managed for more than 10 years (MCF forest; 1230 plants/ha) was less than the community forest managed for equal or less than 10 years (LCF forest; 1314 plants/ha). The results suggest that the size class distribution of the trees resembling inverse-J shaped indicates the good regenerating capability of both forests. After the handover of forests to the community, Sal density had increased rapidly in both the forests. Community management had a significant positive impact on the regeneration of the forest, and thus, the productivity of the forest. Thus, the study of regeneration of forest trees has important implications for the conservation and management of natural forests.
\end{abstract}

Keywords: Community management, saplings, seedlings, size-class distributions, trees

\section{INTRODUCTION}

Natural regeneration is the process of re-growing or reproducing new individual plants in the community. It is the most important process to maintain the stability of the plant species in a community which is affected directly or indirectly by various climatic as well as edaphic factors (Singh \& Singh, 1992). The regeneration status of the forest indicates its health, and a healthy forest ensures good future regenerations. The issue of regeneration is mainly essential on the forest which is under various anthropogenic pressure such as felling trees, grazing, trampling etc. (West et al., 1981). A population with a sufficient number of seedlings and saplings depicts satisfactory regeneration behavior, while an inadequate number of seedlings and saplings of the species in a forest indicates poor regeneration (Tripathi \& Khan, 2007). The diameter distribution of trees has been used to represent the population structure of forest. If the distribution of diameter class is such that a maximum number of individuals is present at the seedling stage and then decreases subsequently at the next level, the model is named as reverse J- shaped curve. This signifies the good regeneration potential of the forest site. In addition to this, sometimes there is a possibility of $\mathrm{J}$ shape curve in an old growth forest as a result of failure in regeneration (Chauhan et al., 2010).

Shorea robusta Geartn has a good population of seedlings in natural forests, but these do not mature in enough numbers to juveniles and young stages (Shankar, 2001). Mortality at the seedling stage of Shorea robusta is high (Chauhan et al., 2010). Several studies have been carried out on the regeneration pattern of Sal forests inside Nepal. Giri et al. (1999) studied the regeneration pattern of $\mathrm{Sal}$ forest in Bardiya National Park. Timilsina et al. (2007) studied the regeneration pattern of Sal dominated forest of Western Terai of Nepal and reported sapling and seedling density of Sal was higher than other associated species. Sapkota et al. (2009) carried out a study on the regeneration of community managed Bhabar lowland and Hill Sal forest in Central Nepal. They found that the regeneration status in both forests was satisfactory evident by the high population of seedlings followed by saplings and adult trees. Kandel (2007) and Acharya and Shrestha (2011) studied the regeneration status of the community forest of Rupandehi district and Sal-dominated Inner Terai forest of Central Nepal separately. Both assessments showed that there was a dominancy of regeneration status of Shorea robusta than other associated species in both study areas.

Awasthi et al. (2015) and Napit (2015) found that regeneration of Sal was higher than other associated species in Lumbini collaborative forests of Rupandehi and Banke National Park, respectively. Regeneration of Sal was higher than other associated species in the Terai and Churia forests of Nepal (DFRS, 2014a, b). 
Regeneration status of sal (Shorea robusta Gaertn.) in community ...

Bhatta and Devkota (2020) studied the regeneration status of Sal (Shorea robusta Gaertn.) forests of Dadeldhura district, Western Nepal and reported that forest management duration supports the regeneration of Sal forest. Thus, the study of regeneration of forest trees has important implications for the conservation and management of natural forests (Tripathi \& Khan, 2007).

Despite its importance, works related to the regeneration pattern of Sal forests has been carried out mainly in national parks and Terai region of Nepal but very few in hilly regions; although other aspects of the forest of Nepal were reported elsewhere (Acharya \& Khadka, 2016; Rana et al., 2016; Bhandari et al., 2018; Bhujel et al., 2019; Bhattarai et al., 2020). Estimation of regeneration patterns on the basis of management practice may play a significant role in biodiversity management. Therefore, this study investigates the temporal variation in the regeneration of the Sal forest of Tanahun district, a part of Gandaki Province, Nepal, that helps for further management of the forest.

\section{MATERIALS AND METHODS}

\section{Study area}

The study area is located in Byas Municipality, Tanahun District of Central Nepal, between $27.91^{\circ}$ to $27.55^{\circ} \mathrm{N}$ latitude and $84.25^{\circ}$ to $85.15^{\circ} \mathrm{E}$ longitude with an elevation of $425 \mathrm{~m}$. - $986 \mathrm{~m}$. from above sea level (Fig. 1). In all the study forests, Shorea robusta was the dominant vegetation with the major associated species such as Schima wallichi, Semecarpous anacardium, Lagerstroemia parviflora and Castanopsis indica. Fodder collection of woody species and cattle grazing were mainly prohibited in all the CFs since it was handed to them. Firewood collection was allowed once a year in all the studied CFs. Cleaning (removal of unwanted shrubs and weeds and singling of desired species); thinning/pruning were the chief silvicultural operations done after the forest has been handed over to the community. The climate of the study area is subtropical monsoonal with four distinct seasons: winter (December to February), spring (March to May), summer (June to August) and autumn (September to November).

Table 1. General information about studied community forests (Data Source: DFO, Tanahun)

\begin{tabular}{lcccccccc}
\hline S.N & Name of CF & $\begin{array}{l}\text { Name of } \\
\text { VDC }\end{array}$ & $\begin{array}{l}\text { Area } \\
\text { (ha) }\end{array}$ & $\begin{array}{l}\text { Elevation } \\
\text { range (m) }\end{array}$ & $\begin{array}{l}\text { No. of } \\
\text { sampling } \\
\text { plots }\end{array}$ & $\begin{array}{l}\text { Year of } \\
\text { handover to } \\
\text { community }\end{array}$ & $\begin{array}{l}\text { Manage- } \\
\text { ment } \\
\text { durations } \\
\text { (year) }\end{array}$ & $\begin{array}{l}\text { Category of } \\
\text { CF } \\
\text { based on } \\
\text { management } \\
\text { duration }\end{array}$ \\
\hline 1. & Foksing CF & Byas-6 & 252.77 & $425-526$ & 26 & 2005 & 10 & $\begin{array}{l}\text { Cf managed for } \\
\leq 10 \text { years }\end{array}$ \\
2. & $\begin{array}{l}\text { Manebanjyang } \\
\text { CF }\end{array}$ & Byas-6 & 146 & $475-798$ & 24 & 2009 & 6 & (LCF)
\end{tabular}

Field survey and data collection The study was conducted in four community managed forests: they are Foksing CF, Manebanjyang CF, Janakalyan CF and Hariyali CF (Table 1). Foksing CF and Manebanjyang $\mathrm{CF}$ are located in Byas Village Development Committee, whereas Janakalyan CF and Hariyali CF are located in the Kyamin Village Development Committee of Byas range post of Tanahun district, Central Nepal. Based upon the information accumulated during the preliminary survey, four CFs which were dominated by Sal were taken and divided into two categories based on the management durations: forest managed by the local community for more than 10 years as MCF forest and managed for equal or less than 10 years as LCF forest.
Preliminary information about the study area was collected in March 2015 by visiting the district forest office (DFO) Tanhun and respective CF offices. We had collected information about forest management activities during field visit from secretary of the forest user's group, Community Forest User's Group (CFUGs) and District Forest Office (DFO) records. Discussion was held with forest user's group to capture information about the forest before and after handover to the community, problems confronted by them in forest management and their complaints and perspective towards their community forests. Vegetation sampling was done by using a stratified random sampling method during 2-18 June 2015. The forest blocks designated by the CFUGs were 
considered as strata. CFUGs are categorized forest blockwise, i.e., separated by walking trail, which considered as strata during the survey. Quadrats were located in different horizontal strata of forests. The horizontal distance between successive quadrats was about $50 \mathrm{~m}$. The number and size of the quadrats were determined by the species area curve method following Mishra (1968). Square quadrat of $10 \mathrm{~m} \times$ $10 \mathrm{~m}$ was sampled for trees, $5 \mathrm{~m} \times 5 \mathrm{~m}$ for shrub layer (including saplings of tree) and $1 \mathrm{~m} \times 1 \mathrm{~m}$ for the seedling of Shorea robusta (Curtis \& McIntosh, 1950). Of hundred quadrats, 50 were laid in LCF and 50 in MCF forests. Each quadrat of $10 \mathrm{~m} \times 10 \mathrm{~m}$ was divided into four subplots from the center of the quadrat, and one subplot was randomly taken for the sampling of the shrub. One of the four corners of the plot was selected randomly where $1 \mathrm{~m} \times 1 . \mathrm{m}$ quadrat was defined: all seedling of Shorea robusta within this quadrat was sampled. In each $\mathrm{CFs}$ about 0.25 ha area of forest was sampled. In each $10 \mathrm{~m} \times 10 \mathrm{~m}$ quadrat, the number of the individual tree [diameter at breast height (1.37), DBH $\geq 10 \mathrm{~cm}$ ] of each species was counted, and DBH of each tree was measured. For shrubs/sampling (DBH $<10 \mathrm{~cm}$, height $>1.37 \mathrm{~m}$ ) the number of individuals of each species was counted. For seedling of Shorea robusta with height $<1.37$, the number of individuals was also counted. Canopy cover $(\%)$ and litter cover (\%) for each plot were estimated visually from the center of the plot following Zobel et al. (1987).
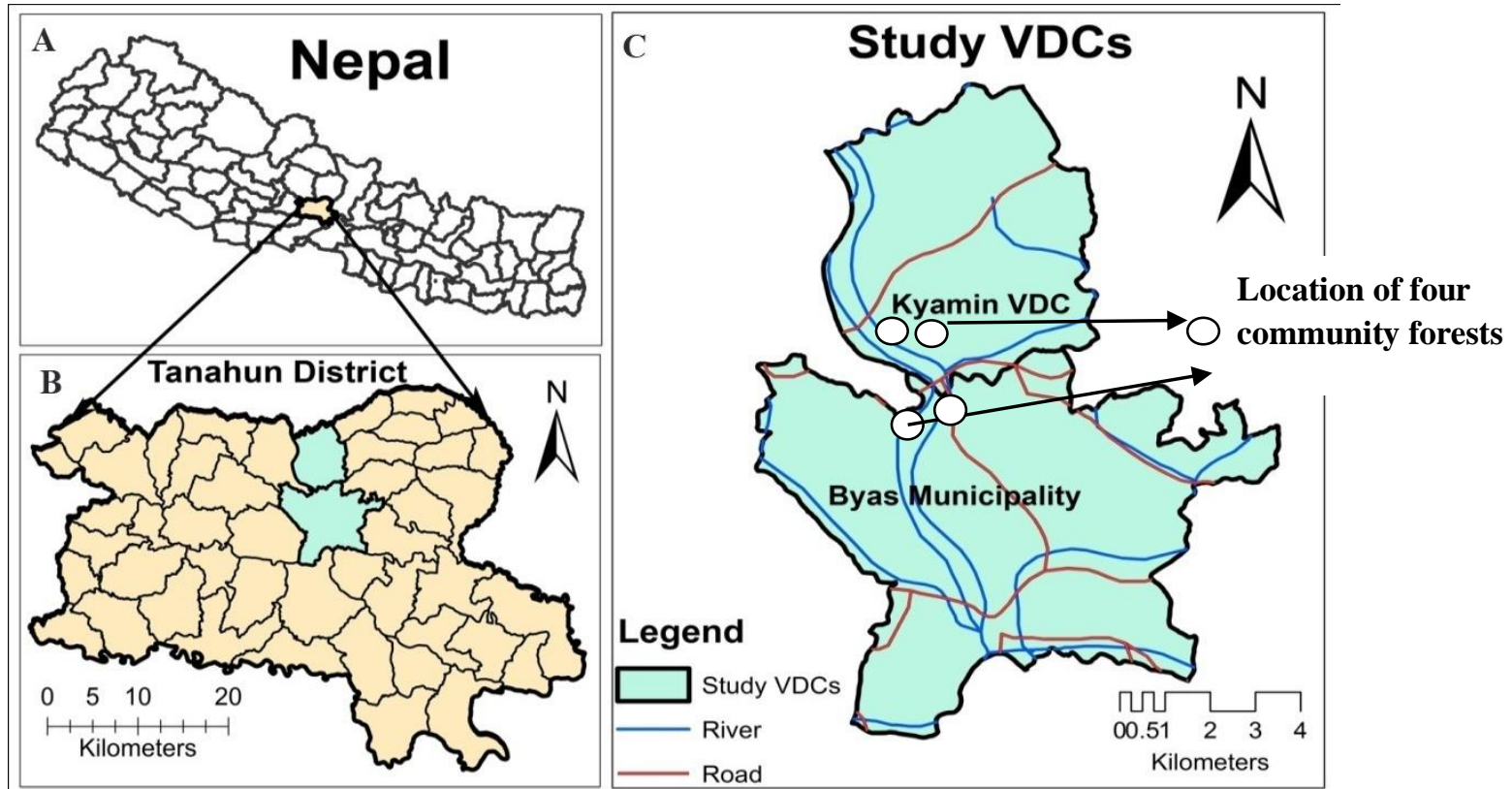

Figure 1. Map of the study area. Figure on th right side shows the location of four community forests.

From each quadrat, about $200 \mathrm{~g}$ soil sample was collected from a depth of $15 \mathrm{~cm}$ from the center of the plot. The soil samples were air-dried in the shade for a week and packed in air-tight plastic bags until laboratory analysis. The soil parameters such as soil organic carbon, $\mathrm{pH}$, total nitrogen, available phosphorus and available potassium were determined at the laboratory of Soil Test Center, Pokhara by applying Walkley- Black rapid titration method, potentiometric method, Kjeldahl method, Olsen's method and flame photometer method, respectively (PCARR, 1980). The plant specimens were identified with the help of literatures Malla et al. (1986), Siwakoti and Varma (1999) and by tallying with the specimens at Tribhuvan University Central Herbarium (TUCH).
The nomenclature of specimens follows Press et al. (2000).

Regeneration status of forests was assessed at three life stages, viz. seedling, sapling and tree, considering seedling as $<137 \mathrm{~cm}$ height, sapling as $<5 \mathrm{~cm} \mathrm{DBH}$ and $>137 \mathrm{~cm}$ height and tree as $\geq 5 \mathrm{~cm} \mathrm{DBH}$ (DFRS, $2014 \mathrm{a}, \mathrm{b})$. The number of trees was recorded in $10 \mathrm{~m}$ $\times 10 \mathrm{~m}$, sapling in $5 \mathrm{~m} \times 5 \mathrm{~m}$ quadrats, while seedlings number was counted in two diagonally opposite $1 \mathrm{~m} \times$ $1 \mathrm{~m}$ quadrats nested within a $10 \mathrm{~m} \times 10 \mathrm{~m}$ quadrat.

\section{Statistical analysis}

To assess the regeneration status of the forest, the density of seedling, sapling and tree were determined 
Regeneration status of sal (Shorea robusta Gaertn.) in community ...

separately following the method described in Zobel et al. (1987). The total number of plants of all species recorded in all $10 \mathrm{~m} \times 10 \mathrm{~m}$ quadrats were divided into different size classes based on $\mathrm{DBH}$ of $5-\mathrm{cm}$ intervals and the density diameter curve was determined (Zobel et al., 1987). Descriptive statistics were applied to generate means and standard error. The mean values of the tree variables, soil properties and regeneration status of plant species were compared between two forest categories by $t$-test. Prior to t-test, data were tested for normality (Shapiro-Wilk test, $p>0.05$ ). Normal data were compared by $t$-test. Correlation analysis was performed to access the relationship of regeneration with different plot variables. All these analyses were done using Microsoft Excel 2007 (Microsoft Corporation 2007) and the Statistical Package for Social Science (SPSS version 20).

\section{RESULTS}

\section{Regeneration status}

The total number of trees and saplings in the LCF forest was $1314 \mathrm{pls} / \mathrm{ha}$ and $8656 \mathrm{pls} / \mathrm{ha}$, respectively, while the total number of trees and saplings were 1230 pls/ha and $9200 \mathrm{pls} /$ ha respectively in MCF forest (Table 2). Tree basal area was higher at MCF forest (9.87 pl/ha) than in LCF $(7.50 \mathrm{pl} / \mathrm{ha})$ (Table 2). Canopy coverage was also higher at MCF than at LCF forest. There was no significant difference in litter coverage at both forests. The total density of seedling, sapling and trees of Sal in LCF forests were 58400, 4728 and 708 pls/ha, respectively, which were higher than the total number of seedlings $(53,400)$, saplings (3920) and trees (638) of MCF forests. The density diameter curve of the tree population of Sal in both LCF and MCF showed a typical reverse J-shaped (Figs. $2 \& 3$ ) . The density of Sal was highest in size class $10-15 \mathrm{~cm}$ in both forests. In size class $30-35 \mathrm{~cm}$, there was an increase in density in MCF forest but decreased in LCF forest. The numbers of individuals were present in only 15 size class in LCF forest while 18 size class in MCF (Figs. 2 \& 3). Trees were smaller in LCF (DBH 10-85c m) than MCF forest (DBH 10 $<100 \mathrm{~cm}$ ). This indicates that the trees in the LCF forest are younger than in the MCF forest. Single size class $(95-100 \mathrm{~cm}$ ) was missing in MCF forest. Stumps of large trees and fallen trees were observed in both forests during the study period.

Table 2. Mean values of different variables and regeneration status studied in community forests of two developmental stages and overall study area (no. of plots; $N=100$ ).

\begin{tabular}{|c|c|c|c|c|c|}
\hline \multirow[t]{2}{*}{ Variables } & \multicolumn{2}{|c|}{ Management duration } & \multirow[t]{2}{*}{ T-value } & \multirow[t]{2}{*}{ p-value } & \multirow{2}{*}{$\begin{array}{l}\text { The overall study } \\
\text { area (mean } \pm \text { SE) }\end{array}$} \\
\hline & MCF forest & LCF forest & & & \\
\hline \multicolumn{6}{|l|}{ Tree variables } \\
\hline Tree Density (plants ha-1) & $1230 \pm 302$ & $1314 \pm 324$ & -0.944 & 0.348 & $1272 \pm 313$ \\
\hline Shrub density (plants ha-1) & $9200 \pm 1888$ & $8656 \pm 2086$ & 2.33 & 0.022 & $8928 \pm 1987$ \\
\hline Total density (plants ha-1) & $10430 \pm 2190$ & $9970 \pm 2410$ & 6.209 & $0.000 \mathrm{a}$ & $10200 \pm 2300$ \\
\hline Tree basal area (plants ha-1) & $9.874 \pm 1.23$ & $7.508 \pm 1.46$ & 0.782 & 0.364 & $8.69 \pm 1.34$ \\
\hline \multicolumn{6}{|l|}{ Stand V ariables } \\
\hline Canopy Coverage $(\%)$ & $70.6 \pm 12.1$ & $68.6 \pm 13.01$ & 0.793 & 0.430 & $69.60 \pm 12.55$ \\
\hline Litter Coverage $(\%)$ & $67.9 \pm 13.4$ & $67.61 \pm 12.62$ & 0.115 & 0.909 & $67.75 \pm 13.01$ \\
\hline \multicolumn{6}{|l|}{ Soil variables } \\
\hline Soil Organic Carbon & $3.46 \pm 1.28$ & $2.89 \pm 1.05$ & 2.42 & 0.017 & $3.17 \pm 1.16$ \\
\hline Soil pH & $5.22 \pm 0.11$ & $5.02 \pm 0.74$ & 1.485 & 0.141 & $5.12 \pm 0.425$ \\
\hline Total nitrogen $(\%)$ & $0.19 \pm 0.008$ & $0.16 \pm 0.006$ & 2.879 & 0.005 & $0.175 \pm 0.007$ \\
\hline Soil Potassium (kg/ha) & $80.5 \pm 41.80$ & $67.5 \pm 37.11$ & 1.65 & 0.002 & $74.0 \pm 39.45$ \\
\hline Soil Phosphorus (kg/ha) & $113.64 \pm 78.95$ & $71.0 \pm 51.65$ & 3.19 & 0.103 & $92.32 \pm 65.30$ \\
\hline \multicolumn{6}{|l|}{ Regeneration Status } \\
\hline Seedling density $(\mathrm{pl} / \mathrm{ha}$ ) of $S$. robusta & $53,400 \pm 1200$ & $58,400 \pm 1380$ & -4.06 & $0.000 \mathrm{a}$ & $55900 \pm 1290$ \\
\hline Sapling(pl/ha) & $9200 \pm 210$ & $8656 \pm 213$ & -4.56 & 0.000 & $8928 \pm 211.5$ \\
\hline Sapling density of Shorea robusta(pl/ha) & $3920 \pm 146$ & $4728 \pm 127$ & -2.407 & 0.018 & $4324 \pm 136.5$ \\
\hline Sal tree density (plants ha-1) & $638 \pm 321$ & $708 \pm 342$ & -0.693 & 0.490 & $673 \pm 331.50$ \\
\hline
\end{tabular}




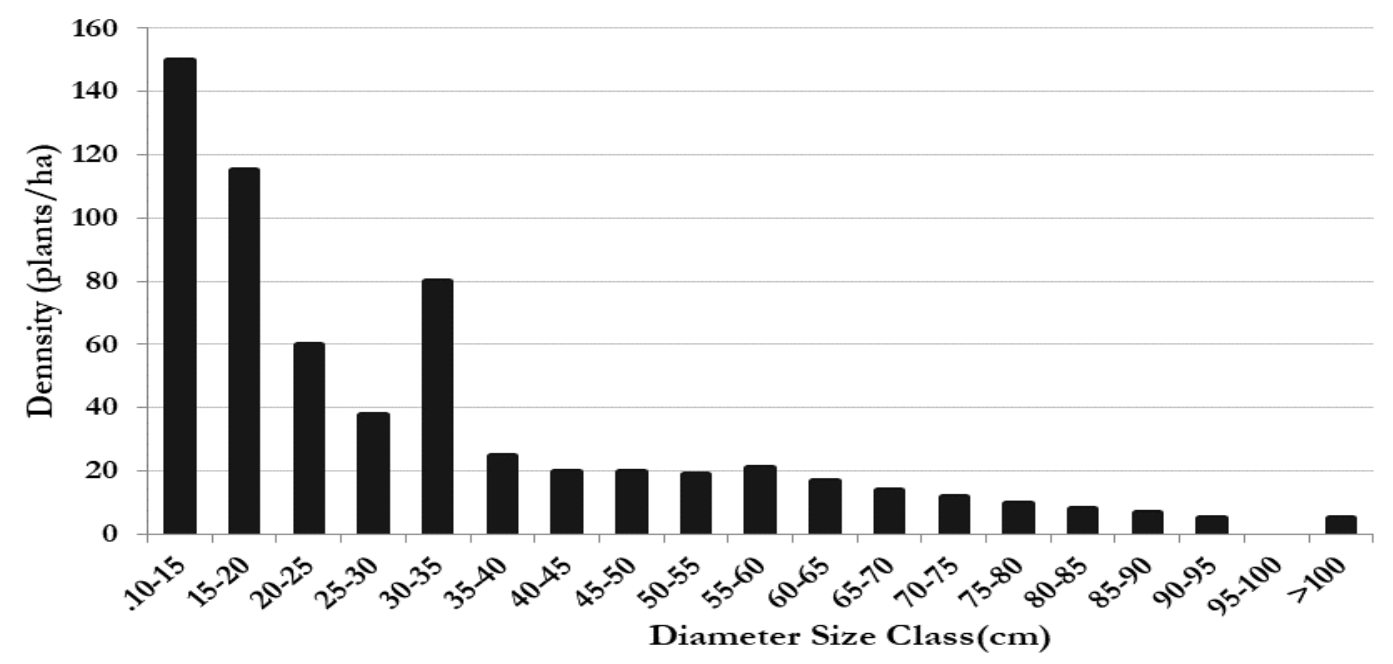

Figure 2. Density-diameter curve of Shorea robusta in MCF forest (managed for more than 10 years).

Influence of soil variables on regeneration status of forest

The soil of both forests was acidic in nature. The mean soil $\mathrm{pH}$ of the MCF forest was $5.22 \pm 0.11$, while that of LCF was $5.02 \pm 0.74$ (Table 2). The mean soil nitrogen $(\mathrm{N})$ content in MCF forest was $0.19 \pm 0.01 \%$ and in LCF forest was $0.16 \pm 0.01 \%$. The average organic carbon (OC) content in the soil of the LCF forests was $2.89 \pm 1.05$ compared to $3.46 \pm 1.28$ in the MCF forest. The average available phosphorus and potassium in the soil of LCF forest were $71.0 \pm 51.65$ and 67.5 \pm 37.11 , respectively (Table 2). Similarly, the average available phosphorus and potassium in the soil of MCF forest were $113.64 \pm 78.95$ and $80.5 \pm 41.80$, respectively. Regeneration of Sal was affected by different soil variables. Seedling growth is negatively related to nitrogen, $\mathrm{pH}$ and canopy cover $(p<0.05)$. The growth of seedlings, saplings and trees was not related to soil organic carbon, potassium, phosphorus, ground vegetation cover and litter cover $(p>0.05)$ (Table 3).

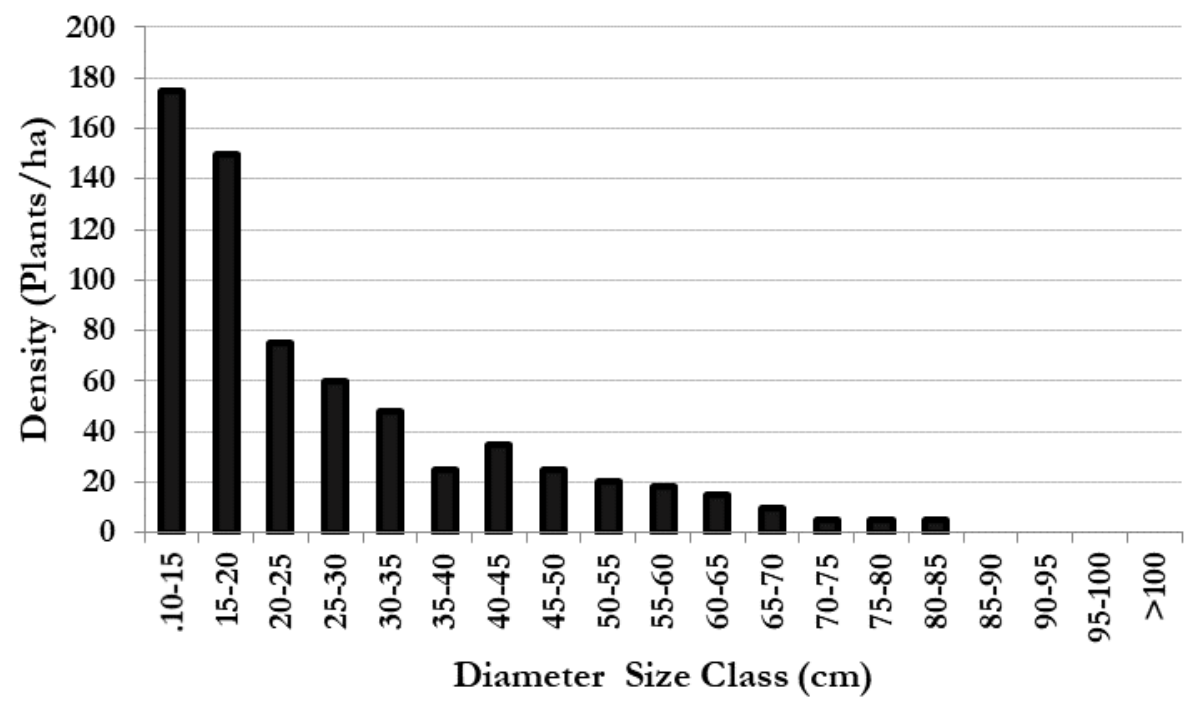

Figure 3. Density-diameter curve of Shorea robusta in LCF forest (managed for equal or less than 10 years). 
Regeneration status of sal (Shorea robusta Gaertn.) in community ...

Table 3. Spearman's correlation coefficient between different variables measured in the sample plots and regeneration (no. of plots; $N=100$ ).

\begin{tabular}{llllllll}
\hline & SOC & $\begin{array}{l}\text { Total } \\
\text { nitrogen }\end{array}$ & $\begin{array}{l}\text { Available } \\
\text { phosphorus }\end{array}$ & Soil pH & $\begin{array}{l}\text { Available } \\
\text { potassium }\end{array}$ & CC & LC \\
\hline Seedlings & 0.430 & $-0.20^{\mathrm{a}}$ & -0.12 & $-0.21^{\mathrm{a}}$ & -0.14 & $-0.25^{\mathrm{a}}$ & 0.056 \\
Saplings & 0.013 & -0.112 & 0.011 & -0.156 & 0.004 & -0.131 & 0.012 \\
Trees & 0.009 & -0.021 & -0.173 & 0.136 & 0.067 & -0.112 & -0.14 \\
\hline \multicolumn{2}{l}{ SOC = soil organic carbon; CC $=$ canopy coverage; LC = Litter coverage; a Represents significant correlation $(p<0.05)$} &
\end{tabular}

\section{DISCUSSION}

Seedling, sapling and tree density were higher in LCF forests than in MCF forests. Sapling and seedling densities of Sal also were higher in LCF forest than in MCF forest. Since the total basal area of trees was lower in LCF forest than in MCF forest, it can be predicted that the tree canopy of LCF forest was more open in comparison to MCF forest. Canopy cover plays an important role in the establishment of seedlings and saplings. For the light demanding species like Sal, an open canopy allowed ample light to reach the forest understory and made the light environment favorable for abundant growth of their seedlings and saplings (Gautam \& Devoe, 2006). The seedling density of Sal showed a negative correlation with coverage. Regeneration of tree species is affected by light, canopy density, soil nutrients and anthropogenic pressure (Shrestha et al., 2007; Bhatta \& Devkota, 2020). The greater number of saplings in the stands indicates the composition of future vegetation (Swaine \& Hall, 1988).

The density diameter curve of both forests showed an inverse $\mathrm{J}$ - shaped curve, which indicates sustainable regeneration (Vetaas, 2000). The presence of 58,400 seedlings, 4,728 saplings and $708 \mathrm{Pl} /$ ha of Sal in LCF forest and 53,400 seedlings, 3,920 saplings and 638 $\mathrm{Pl} /$ ha of $\mathrm{Sal}$ in MCF forest indicate good regeneration of Sal. In both Sal forests, regeneration is fine, as evidenced by the high population density of seedlings followed by sapling and adult trees. In Nepal, sustainable regeneration of Sal has been reported from both terai (Sapkota et al., 2009; Bhatta \& Devkota, 2020) and hills (Rai et al., 1999; Shrestha, 2005). However, Rai et al. (1999) found that the regeneration was not sustainable in a natural dense forest with a high density of larger trees. Similarly, Shrestha (2005) found that Sal regeneration was discontinuous in the Khari forest of Dhading district. However, Shrestha (2005) found bell-shaped size class distribution, which indicates the lack of sustainable regeneration in the mid-hill region of Nepal. Since the use of Sal has been restricted, S.wallichi was the most preferred species and being harvested to meet timber and fuelwood needs by both forests user groups.
In both forests, the lowest diameter class had the highest tree density representing trees has been established after conservation through community forestry. This indicates after the handover of forests to the community, Sal density had increased rapidly in both the forests. The density of trees decreased exponentially with increasing $\mathrm{DBH}$ class in both the forests except in DBH class 30-35 for MCF forest. Decreasing of diameter class distribution exponentially with increasing $\mathrm{DBH}$ are characteristics for species with continuous regeneration (Khamyong et al. 2004). Densities of larger trees are lower in LCF forest in comparison to MCF forest. This might be due to management practices conducted by forest user groups. However, density was higher in LCF forest than in MCF forest, and within a few decades, this forest may change into a dense forest with a closed canopy.

All the CFs had separate forest management plans that were prepared with the consensus of the forest user group. In both the forest, thinning has been done as a major management practice. In MCF forests, forest management communities have an interest in multiple species, so they do not remove all low-quality timber species, shrubs and climbers. But in LCF forest, the major objective of thinning was to promote regeneration of Sal and limited timber yielding species that have high economic value. Since most of the forest user group (FUG) members have installed biogas plants and L.P.G gas, the demand for wood was quite low. Collection of litter had not been noticed in both the forests as litter is the main source of organic matter and plant nutrients, which can be considered as good management practices. In both forests, communities used forest products mainly for fulfilling basic needs such as grass for livestock, firewood and timber for building. At the same time, further depletion of the forests had been protecting by them. Communities were preventing unauthorized deforestation activities such as unplanned forest fires and illegal harvesting of forest products. Soil variables had a significant impact on the regeneration pattern of Sal in the study area. Seedling growth is negatively 
related to nitrogen, $\mathrm{pH}$ and canopy cover $(p<0.05)$. The growth of seedlings, saplings and trees was not related to soil organic carbon, potassium, phosphorus, ground vegetation cover and litter cover $(p>0.05)$. Chauhan et al. (2010) observed the significant impact of soil parameters on seedling and tree density in the planted and natural Sal forest of India. Sapkota et al. (2009). Adhikari et al. (2017) and Bhatta and Devkota (2020) mentioned that a low canopy cover is suitable for the regeneration of Sal.

\section{CONCLUSIONS}

The total tree density varied with the management duration of the forest. The total tree density of community forest managed for more than 10 years was higher than the community forest managed for equal or less than 10 years. The results suggest that the size class distribution of the trees resembling inverse-J shaped indicates the good regenerating capability of both forests. After the handover of forests to the community, Sal density had increased rapidly in both the forests.

\section{ACKNOWLEDGEMENTS}

We are thankful to Prof. Dr. Mohan Siwakoti, former head of Central Department of Botany for providing necessary support during completion of the work.

\section{AUTHOR CONTRIBUTIONS}

$\mathrm{AD}$ conceptualized, designed the study, revised and finalized the manuscript; PP collected and analyzed data, and prepared first draft of the manuscript.

\section{CONFLICT OF INTEREST}

The authors declare no competing interests.

\section{DATA AVAILABILITY STATEMENT}

The data that support the findings of this study are available from the corresponding author, upon reasonable request.

\section{REFERENCES}

Acharya, R., \& Shrestha, B.B. (2011). Vegetation structure, natural regeneration and management of Parroha community forest in Rupandehi district, Nepal. Scientific World, 9, 70-81.

Acharya, S., \& Khadka, U. (2016). Loss of tree biomass in Jure landslide, Sindhupalchowk, Nepal. Journal of Institute of Science and Technology, 21(1), 65-70.

Adhikari, B., Kapkoti, B., Lodhiyal, N., \& Lodhiyal, L.S. (2017). Structure and regeneration of Sal (Shorea robusta Gaertn. f.) forests in Shivalik region of Kumaun Himalaya, India. Indian Journal of Forestry, 40, $1-8$.
Awasthi, A., Bhandari, S.K., \& Khanal, Y. (2015). Does scientific forest management promote plant species diversity and regeneration in sal (Shorea robusta) forest? A case study from Lumbini collaborative forest, Rupandehi, Nepal. Banko Jankari, 25, 20-29.

Bhandari, A., Khadka, U., \& Kanel, K. (2018). Ecosystem services in the mid-hill forest of western Nepal: A case of Panchase protected forest. Journal of Institute of Science and Technology, 23(1), 10-17.

Bhatta, S.P., \& Devkota, A. ( 2020). Community structure and regeneration status of Sal (Shorea robusta Gaertn.) forests of Dadeldhura district, Western Nepal. Community Ecology, 21, 191-201 https://doi.org/10.10 07/s42974-020-00021-8.

Bhattarai, K.P., Mandal, T.N., \& Gautam T.P. (2020). Effect of altitude on nutrient concentration, nutrient stock and uptake in fine root of sal (Shorea robusta Gaertn.) forest in terai and hill areas of Eastern NepaL Journal of Institute of Science and Technology, 25(1), 24-29.

Bhujel, K., Byanju, R., \& Gautam, A. (2019). Wildlife dynamics and its effects on the forest resources and public property in Nepal. Journal of Institute of Science and Technology, 23(1), 61-68.

Chauhan, D.S., Singh, B., Chahun, S., Dhanai, C.S., \& Todaria, N.P. (2010). Regeneration and plant diversity of natural and planted Sal (Shorea robusta Geartn. F.) forests in the Terai-Bhabhar of Sohagibarwa Wildlife Sanctuary, India. The Journal of American Science, 6(3), 32-45.

Curtis, J.T., \& McIntosh, R.D. (1950). The interrelations of certain analytic and synthetic phyto-sociological characters. Ecology, 31, 434-455.

DFRS. (2014a). Terai forests of Nepal (2010-2012). Kathmandu: Forest resource assessment Nepal project, Department of Forest Research and Survey, Ministry of Forests and Soil Conservation.

DFRS. (2014b). Churia forests of Nepal (2011-2013). Kathmandu: Forest resource assessment Nepal project, Department of Forest Research and Survey, Ministry of Forests and Soil Conservation.

Gautam, K.H., \& Devoe, N.N. (2006). Ecological and anthropogenic niches of Sal (Shorea robusta Gaertn. f.) forest and prospects for multiple-product forest management- a review. Forestry, 79, 81-101.

Giri, A., Aryal, B., Bhattarai, B., Ghimire, S.K., Shrestha, K.K., \& Jha, P.K. (1999). Vegetation Composition, Biomass production and Regeneration in Shorea robusta forests in the Royal Bardia National Park, Nepal. Nepal Journal of Science and Technology, 1, 7-56.

Kandel, D.R. (2007). Vegetation Structure and Regeneration of Sal (Shorea robusta Gaertn.) in Community Managed Forests of Inner Terai, Central Nepal (M.Sc. Thesis). Central Department of Botany, Tribhuvan University, Kathmandu, Nepal.

Khamyong, S., Lykke, A.M., Seramethakun, D., \& Barfod, A.S. (2004). Species composition and 
Regeneration status of sal (Shorea robusta Gaertn.) in community ...

vegetation structure of an upper montane forest at summit of Mt. Doi Inthanon, Thailand. Nordic Journal of Botany, 23, 83-97.

Malla, S.B., Rajbhandary, S.B., Shrestha, T.B., Adhikari, P.M., Adhikari, S.R., \& Shakya, P.R. (1986). Flora of Kathmandu Valley. Kathmandu: Bulletin of Medicinal Plants of Nepal. No. 11. Department of Medicinal Plants.

Mishra, R. (1968). Ecology Workbook. Oxford and IBH Publishing Company, Calcutta.

Napit, R. (2015). Species diversity, forest community structure and regeneration in Banke National Park, Nepal. Nepal Journal of Science and Technology, 16, 17-30.

PCARR. (1980). Standard methods of analysis for soil, plant tissue, water and fertilizer. Farm Resources and Systems Research Division, Philippine Council for Agriculture and Resources Research, Los Banos, Laguna.

Press, J.R., Shrestha, K.K., \& Sutton, D.A. (2000). Annotated checklist of flowering plants of Nepal. London: The Natural History Museum.

Rai, S.N., Dutta, I.C., Haque, S., Khanal, B.B., Chaurasia, J.P., \& Indu, I.P. (1999). Ecology and growth of Shorea robusta in central Nepal. In: Mathema, P., Dutta, I.C., Balla, M.K., \& Adhikari, S.N. (Eds.), Sustainable Forest Management (pp. 117-125). Proceeding of International Seminar (1998) Aug 31 Sept.2, Pokhara (Nepal); Institute of Forestry, Tribhuvan University.

Rana, P., Koirala, M., Bhuju, D., \& Boonchird, C. (2016). Population structure of Rhododendron campanulatum D. Don and associated tree species along the elevational gradient of the Manaslu Conservation Area, Nepal. Journal of Institute of Science and Technology, 21(1), 95-102.

Sapkota, I.P., Tigabu, M., \& Oden, C.P. (2009). Spatial distribution, advanced regeneration and stand structure of Nepalese Sal (Shorea robusta) forests subject to disturbance of different intensities. Forest Ecology and Management, 257, 1966-1975.
Shankar, U. (2001). A case of high tree diversity in a Sal (Shorea robusta) dominated lowland forest of Eastern Himalaya: Floristic composition, regeneration and conservation. Current Science, 81(7), 776-786.

Shrestha, B.B., Lekhak, H.D., Ghimire, B., \& Jha, P.K. (2007). Regeneration of treeline Birch (Betula utilis D. Don) forest in a Trans-Himalayan Dry Valley in Central Nepal. Mountain Research and Development, 27(3), 259-266.

Shrestha, B.B. (2005). Fuel wood consumption, management and regeneration of two community forests in central Nepal. Himalayan Journal of Science, 3(5), 75.

Singh, J.S., \& Singh, S.P. (1992). Forests of Himalaya, Gyanodaya Prakashan, Naintal, India.

Siwakoti, M., \& Varma, S.K. (1999). Plant diversity of Eastern Nepal:Flora of plains of Eastern Nepal. Dehradun: Bishen Singh Mahendra Pal Singh.

Swaine, M.D., \& Hall, J.B. (1988). The mosaic theory of forest regeneration and the determination of forest composition in Ghana. Journal of Tropical Ecology, 4, 253-269.

Timilsina, N., Ross, M.S., \& Heinen, J.T. (2007). A community analysis of Sal (Shorea robusta) forests in the western Terai of Nepal. Forest Ecology and Management, 241, 223-234.

Tripathi, R.S., \& Khan, M.L. (2007). Regeneration dynamics of natural forests- A review. Proceedings of the Indian National Science Academy, 73, 167-195.

Vetaas, O.R. (2002). The effect of environmental factors on the regeneration of Quercus semecarpifolia $\mathrm{Sm}$. in Central Himalaya, Nepal. Plant Ecology, 146, 137-144.

West, D.C., Shugart, H.H., \& Ranney, J.W. (1981). Population structure of forests over a large area. Tropical Ecology, 230, 136-150.

Zobel, D.B., Behan, M.J., Jha, P.K., \& Yadav, U.K.R. (1987). A practical manual for ecology. Ratna Book Distributors, Bagbazar, Kathmandu, Nepal. 